\title{
IRRIGATION AND NITROGEN MANAGEMENT IN PROTEIN CONTENT AND QUALITY OF COMMON BEAN SEEDS
}

\author{
MANEJO DA IRRIGAÇÃO E NITROGÊNIO NO TEOR DE PROTEÍNA E \\ QUALIDADE DE SEMENTES DE FEIJÃO
}

\author{
Matheus Gustavo da SILVA'; Aliston Flávio de SOUZA무 Gustavo Henrique Ferreira da SILVA'; \\ Adriano da Silva LOPES'; Paulo Eduardo TEODORO² \\ 1. Universidade Estadual do Mato Grosso do Sul, Unidade Universitária de Aquidauana, MS, Brasil; 2. Universidade Federal do Mato \\ Grosso do Sul, Campus de Chapadão do Sul, MS, Brazil. eduteodoro@ hotmail.com
}

\begin{abstract}
The aim of this study was to investigate the influence of different irrigation managements and nitrogen topdressing rates on the protein content and physiological quality of common bean seeds. Trial was conducted at Universidade Estadual de Mato Grosso do Sul, Unidade Universitária de Aquidauana from June to September, 2010. Experimental design was a randomized block in a split plot, using three blocks and two replications within each block. Plots corresponded to three irrigation managements: Hargreaves-Samani, Penman-Montheith and Class A pan. Subplots were represented by four $\mathrm{N}$ topdressing rates (zero, 50,100 and $150 \mathrm{~kg} \mathrm{ha}^{-1}$ ). The following variables were evaluated: 100seed mass, nitrogen and crude protein content in seeds, germination at field, germination at laboratory, accelerated aging and germination speed index. There was a significant interaction between the different irrigation management and nitrogen topdressing rates for nitrogen and crude protein content in seeds, germination at laboratory and emergence speed index. Levels between 70 and $120 \mathrm{~kg} \mathrm{ha}^{-1} \mathrm{~N}$ in conjunction with irrigation management by Hargreaves-Samani method provide better physiological quality of common bean seeds.
\end{abstract}

KEYWORDS: Phaseolus vulgaris. Germination. Vigor tests.

\section{INTRODUCTION}

Common bean (Phaseolus vulgaris L.) plays an important role in Brazilian food as it constitutes the main source of vegetable protein, especially for low-income people, even being a source of iron, carbohydrates and fiber (GOMES JUNIOR et al., 2005). In Brazil, common bean has been grown on a large diversity of production systems, achieving yields higher than $4000 \mathrm{~kg} \mathrm{ha}^{-1}$ under irrigation systems (FARINELLI et al., 2006), however, these figures do not reflect the overall average of domestic production, which is currently of $939 \mathrm{~kg}$ $\mathrm{ha}^{-1}$ (CONAB, 2013).

According to Farinelli et al. (2006), one of the main reasons for the low national average yield is the use of seeds with lower quality, which results from the interaction of genetic, physical, sanitary and physiological components, this latter being influenced by the environment in which the seeds are produced (CARVALHO; NAKAGAWA, 2000). Physiological quality is related to the seeds ability to perform its vital functions, characterized by longevity, germination and vigor. Thus, the effects on quality are generally translated by a decrease in germination percentage, increased abnormal seedling and reduced seedling vigor (TOLEDO et al., 2009).

In Brazil, fertilization with nitrogen $(\mathrm{N})$ as topdressing is a practice that has provided increments on the physiological quality and protein content of common bean seeds (BORDIN et al., 2003; GOMES JUNIOR et al., 2005; FARINELLI et al., 2006; TOLEDO et al., 2009; GOMES JUNIOR et al., 2010). The nutrient wich the common bean absorbs the most is $\mathrm{N}$, being necessary for the chlorophyll synthesis as part of this molecule is involved in the photosynthesis. In addition, the $\mathrm{N}$ participates of the amino acid composition, having a direct effect on protein content in the seeds (GOMES JUNIOR et al., 2005).

However, another variable that must be analyzed together with the nitrogen topdressing is the irrigation management, since this practice is commonly used in the common bean crop. Pacheco et al. (2012) report besides being the main factor responsible for the common bean cultivation in the winter, the irrigation also allows this culture to express its productive potential. Thus, the aim of this study was to evaluate the influence of different irrigation managements and nitrogen topdressing rates on the protein content and physiological quality of common bean seeds.

\section{MATERIAL AND METHODS}

Trial was carried out at Universidade Estadual de Mato Grosso do Sul, Unidade Universitária de Aquidauana $\left(20^{\circ} 20^{\prime} \mathrm{S}, 55^{\circ} 48^{\prime} \mathrm{W}\right.$ and average altitude of $174 \mathrm{~m}$ ), from June to 
September 2010. The climate, according to Köppen classification is Aw, defined as hot sub-humid tropical climate, with rainy season in summer and dry in winter (ALVARES et al., 2014). Accumulated rainfall, average temperature and relative humidity, during the trial, were $18.61 \mathrm{~mm}$, $23.1^{\circ} \mathrm{C}$ and $56.9 \%$, respectively. The soil was classified by Schiavo et al. (2010) as Ultisol dystrophic, physically deep and moderately drained, whose chemical properties are shown in Table 1.

Table 1. Experimental area chemical soil analysis. Aquidauana, MS, 2010.

\begin{tabular}{cccccccccccc}
\hline Layer & $\mathrm{pH}$ & $\mathrm{P}$ & $\mathrm{OM}$ & $\mathrm{K}$ & $\mathrm{Ca}$ & $\mathrm{Mg}$ & $\mathrm{Al}$ & $\mathrm{H}+\mathrm{Al}$ & $\mathrm{S}$ & $\mathrm{T}$ & $\mathrm{V}$ \\
\hline$(\mathrm{m})$ & $\left(\mathrm{H}_{2} \mathrm{O}\right)$ & \multicolumn{2}{c}{$\mathrm{mg} \mathrm{dm}^{-3}$} & & & $------------\mathrm{mmol}_{\mathrm{c}} \mathrm{dm}^{-3}-------------$ & & $(\%)$ \\
\hline $0.0-0.2$ & 5.4 & 56.6 & 27.1 & 4.80 & 44 & 10 & 0.0 & 33 & 58.8 & 91.8 & 64.1 \\
$0.2-0.4$ & 6.9 & 40.5 & 16.8 & 2.00 & 51 & 6 & 0.0 & 14 & 59.0 & 73.0 & 80.8 \\
\hline
\end{tabular}

OM: organic matter.

Experimental design was a randomized block in split plot, using three blocks and two replications within each block. The plots corresponded to three irrigation management based on reference evapotranspiration (ETo) estimate methods. Subplots were represented by four N topdressing rates $\left(0,50,100\right.$ and $\left.150 \mathrm{~kg} \mathrm{ha}^{-1}\right)$.

Irrigation management consisted by:

a) Hargreaves-Samani method (HS): developed in California, in semi-arid conditions, from data obtained in lysimeters with grass and described according to equation (PEREIRA et al., 1997): $\mathrm{ETo}_{(\mathrm{HS})}=0.0135 \mathrm{kt} \mathrm{Ra}\left(\mathrm{T}_{\max }-\mathrm{T}_{\min }\right)^{0.5}(\mathrm{~T}+$ 17.8), wherein $\mathrm{ETo}_{(\mathrm{HS})}=$ reference evapotranspiration, according to HS method $\left(\mathrm{mm} \mathrm{d}^{-}\right.$ $\left.{ }^{1}\right)$; $\mathrm{kt}=$ empirical coefficient, used in continental regions $(0.162) ; \mathrm{Ra}=$ extraterrestrial radiation $(\mathrm{mm}$ $\left.\mathrm{d}^{-1}\right) ; \mathrm{T}=$ average air temperature $\left({ }^{\circ} \mathrm{C}\right)$; Tmax $=$ maximum air temperature $\left({ }^{\circ} \mathrm{C}\right)$; e Tmin $=$ minimum air temperature $\left({ }^{\circ} \mathrm{C}\right)$.

b) Penman-Montheith method FAO-56 (PM): recommended by FAO, with stomatal resistance of $70 \mathrm{~m} \mathrm{~s}^{-1}$, grass height fixed at $0.12 \mathrm{~m}$ and albedo of $23 \%$, whose estimate is given using the following equation 2 (ALLEN et al., 1998):

$$
\mathrm{ETo}_{(\mathrm{PM})}=\frac{0.408 \Delta(\mathrm{Rn}-\mathrm{G})+\gamma\left(\frac{900 \mathrm{U}_{2}}{\mathrm{~T}+273}\right)(\mathrm{es}-\mathrm{ea})}{\Delta+\gamma\left(1+0.34 \mathrm{U}_{2}\right)},
$$

wherein $\mathrm{ETo}_{(\mathrm{PM})}=$ reference evapotranspiration, by $\mathrm{PM}$ method $\left(\mathrm{mm} \mathrm{d}^{-1}\right) ; \mathrm{Rn}=$ net radiation $\left(\mathrm{MJ} \mathrm{m}^{-2} \mathrm{~d}^{-}\right.$ $\left.{ }^{1}\right) ; \mathrm{G}=$ heat flow in the soil $\left(\mathrm{MJ} \mathrm{m}^{-2} \mathrm{~d}^{-1}\right) ; \mathrm{D}=$ water vapor saturation curve declination $\left(\mathrm{kPa}^{\circ} \mathrm{C}^{-1}\right) ; \mathrm{U} 2=$ average wind speed, $2.0 \mathrm{~m}$ above the soil surface $(\mathrm{m}$ $\left.\mathrm{s}^{-1}\right) ; \mathrm{T}=$ average air temperature $\left({ }^{\circ} \mathrm{C}\right)$; es $=$ vapor saturation pressure $(\mathrm{kPa})$; ea $=$ vapor current pressure $(\mathrm{kPa})$; and $\mathrm{g}=$ psychrometric constant $(\mathrm{kPa}$ $\left.{ }^{\circ} \mathrm{C}^{-1}\right)$.

c) Class A pan method (CAP): consisting of a cylindrical pan with galvanized steel sheet with $1.21 \mathrm{~m}$ in diameter and $0.255 \mathrm{~m}$ deep, aluminized color, placed on top of a wooden pallet and positioned $15.0 \mathrm{~cm}$ from the soil in grassy area, with edge $10.0 \mathrm{~m}$. Water was placed inside the pan, the level being measured in a reassuring pit of $0.25 \mathrm{~m}$ height and $0.1 \mathrm{~m}$ diameter, whose edge was affixed to a micrometer screw, measuring the minimum variations up to $0.01 \mathrm{~mm}$ water evaporation. At the pit bottom, there is an orifice that allows the entry of water, for carrying out measurements (ALLEN et al., 1998). The equation used for this method is: $\mathrm{ETo}_{(\mathrm{TCA})}=\mathrm{kp} \mathrm{ECA}$, wherein $\mathrm{ETo}_{(\mathrm{TCA})}=$ reference evapotranspiration, by CAP method $\left(\mathrm{mm} \mathrm{d}^{-1}\right)$; ECA $=$ evaporation observed in $\mathrm{CAP}\left(\mathrm{mm} \mathrm{d}^{-1}\right)$; and $\mathrm{kp}=$ pan coefficient (0.75). The $\mathrm{kp}$, as constant of 0.75 , was extracted from table proposed by Allen et al. (1998), considering the wind speed lower than $2.0 \mathrm{~m}$ $\mathrm{s}^{-1}$ and relative humidity between $40 \%$ and $70 \%$.

The crop evapotranspiration was determined using the dry bean coefficient, which varied according to its phenology, vegetative stage being 0.35 to 1.15 , the reproductive phase of 1.15 and the phase comprising the filling grains and the maturity of 1.15 and 0.25 (ALLEN et al., 1998). Crop evapotranspiration was calculated using the equation: $\mathrm{ETc}=\mathrm{ETo} \mathrm{kc}$, which $\mathrm{ETc}=$ crop evapotranspiration $\left(\mathrm{mm} \mathrm{d}^{-1}\right)$; ETo $=$ reference evapotranspiration $\left(\mathrm{mm} \mathrm{d}^{-1}\right)$ and $\mathrm{kc}=\mathrm{crop}$ coefficient (adimensional).

Conventional sprinkler irrigation system was installed on June 11, 2010, three days after sowing of common bean. For performing the three irrigation management, the area was divided into three blocks of $84.0 \times 24.0 \mathrm{~m}, 12.0 \mathrm{~m}$ spaced. The plots were $24.0 \times 24.0 \mathrm{~m}$, spaced apart by $6.0 \mathrm{~m}$ in the same block. Inside the plots, there were four sub plots containing $\mathrm{N}$ topdressing rates, with two replications, totaling eight subplots of three lines $(0.45 \mathrm{mx} 5.0 \mathrm{~m})$, covering an area of $6.75 \mathrm{~m}^{2}$. The results for irrigation management are shown in Table 2. 
Irrigation and nitrogen management...

SILVA, M. G. et al.

Table 2. Maximum (ETcmax), average (ETcmed) and minimum (ETcmin) evapotranspiration, irrigation blade (IB), total blade (TB) and irrigation frequency (IF) depending on the irrigation management over the common bean cycle grown in Aquidauana, MS, 2010.

\begin{tabular}{ccccccc}
\hline $\begin{array}{c}\text { Irrigation } \\
\text { management }\end{array}$ & ETcmax & $\begin{array}{c}\text { ETcmed } \\
\text {--------------mm day }\end{array}$ & ETcmin & IB & TB & IF \\
days
\end{tabular}

It was held weed desiccation with the application of $360 \mathrm{~g}$ ha $^{-1}$ active ingredient glyphosathe in a spray volume of $300 \mathrm{~L} \mathrm{ha}^{-1}$ of commercial product. Common bean was sown mechanically on June 8, 2010, winter period, using the Pérola cultivar, with $0.45 \mathrm{~m}$ between rows and 16 plants $\mathrm{m}^{-1}$. Base fertilization occurred at the time of sowing and consisted of $240 \mathrm{~kg} \mathrm{ha}^{-1}$ formulated 04-20-20. For weed control in post-emergence, it was carried out at 20 days after crop emergence application of active and selective ingredients fluazifop-p-butyl + fomesafen at $125+125 \mathrm{~g} \mathrm{ha}^{-1}$ with the $300 \mathrm{~mL} \mathrm{ha}{ }^{-1}$ of commercial product according to Silva et al. (2015). Topdressing occurred when the plants were in V4 stage, as urea $(45 \% \mathrm{~N})$, in the respective rates.

At the time of full flowering of common bean (R6 stage), the two central rows of each subplot were collected. After harvesting and manual threshing, the seeds were stored in laboratory for following assessments:

100-seed mass: determined by the one hundred seeds mass, randomly chosen from the total sample of each subplot with their values being adjusted to $13 \%$ moisture;

Germination: 200 seeds were used for each subplot, divided into four sub-samples of 50 seeds. They have been deposited on paper towels (RP), moistened with water equivalent to 2.5 times the substrate weight, and maintained at temperature of $25^{\circ} \mathrm{C}$, being evaluated the normal seedlings on the fifth and ninth days after the test facility (BRASIL, 2009).

Germination speed index: was made together with the germination tests, where from the fifth day after assembling the test was made by counting the number of germinated seeds, the same being repeated daily until the ninth day. Germination speed index was calculated according to Maguire (1962), represented by formula: IVG $=\mathrm{G} 1 / \mathrm{N} 1+$ $\mathrm{G} 2 / \mathrm{N} 2+\ldots \ldots \mathrm{Gn} / \mathrm{Nn}$, wherein $\mathrm{G} 1, \mathrm{G} 2$ and $\mathrm{Gn}$ is the number of germinated diaspores and N1, N2 and $\mathrm{Nn}$, is the number of days after sowing.

Seedling emergence at field: it used 200 seeds (four repetitions with 50 seeds) per treatment, sown in furrows, with line spacing of $0.50 \mathrm{~m}$, at a depth of $0.04 \mathrm{~m}$. Counting was made considering the total number of emerged plants 21 days after sowing (VIEIRA; CARVALHO, 2004).

Accelerated aging: 200 seeds from each subplot were used, divided into four subplots with 50 seeds (repetitions), employing Gerbox plastic boxes with individual compartment (mini-chambers) having therein a stainless steel screen tray on which were placed 50 seeds. On plastic boxes were added $40 \mathrm{ml}$ of distilled water, which were closed and kept at $42^{\circ} \mathrm{C}$ for $72 \mathrm{~h}$ (MARCOS FILHO, 1999).

Total nitrogen and crude protein content in seeds: a sample of $20 \mathrm{~g}$ of seeds was removed from the total mass of seeds obtained in each subplot. These seeds were milled in centrifugal mills, with the sieve of $0.2 \mathrm{~mm}$ in diameter. Subsequently, the nitrogen content in seeds was determined according to the Kjeldahl method. With the total nitrogen content in the seeds, it used the conversion factor of 6.25 for the calculation of crude protein present in seeds (TEDESCO et al., 1995).

Variables analyzed were submitted to the Shapiro-Wilk's test to verify the residuals normality and subsequently submitted to analysis of variance. Qualitative factor (irrigation management) was submitted to the means comparison by Tukey's test and quantitative ( $\mathrm{N}$ topdressing rates) to polynomial regression analysis. The best fitted equation was chosen according to the coefficient of determination and the regression coefficients significance was tested by the t-test and corrected based on the residues from the analysis of variance. All analyzes were performed with Sisvar statistical software (FERREIRA, 2011).

\section{RESULTS AND DISCUSSION}

There was a significant interaction between the different irrigation management and nitrogen topdressing rates for nitrogen and crude protein content in seeds, germination at laboratory and emergence speed index (Table 3). The 100-seed mass was not affected by any study factor, possibly because this variable is related to genotypic cultivar 
features, having lower variation percentage resulting from the changes in the cultivation (CRUSCIOL et al., 2003). On the other hand, the germination at field showed quadratic adjustment in response to $\mathrm{N}$ rates, reaching maximum point with the $100 \mathrm{~kg} \mathrm{ha}^{-1}$ approximate rate. Similar results were achieved by Oliveira et al. (2003), who observed quadratic adjustments to this variable in response to $\mathrm{N}$ rates.

Tabela 3. Calculated $F$ values and coefficient of variation (CV) for 100-seed mass (HSM), nitrogen content in seeds (NS), crude protein content in seeds (CPS) germination at field (GF), germination at laboratory (GL), accelerated aging (AA) and germination speed index (GSI) of common bean according to the different irrigation management $(\mathrm{I})$ and nitrogen rates $(\mathrm{N})$.

\begin{tabular}{|c|c|c|c|c|}
\hline Variable & Irrigation management (I) & Nitrogen rates $(\mathrm{N})$ & $\mathrm{I} \times \mathrm{N}$ & $\mathrm{CV}(\%)$ \\
\hline HSM & $2.6^{\mathrm{ns}}$ & $0.5^{\mathrm{ns}}$ & $1.7^{\mathrm{ns}}$ & 7.2 \\
\hline NS & $27.7 * *$ & $1.1^{\mathrm{ns}}$ & $9.8 * *$ & 6.9 \\
\hline CPS & $27.7 * *$ & $1.1^{\mathrm{ns}}$ & $9.8 * *$ & 7.2 \\
\hline $\mathrm{GF}^{1}$ & $1.1^{\mathrm{ns}}$ & $4.7 * *$ & $1.2^{\mathrm{ns}}$ & 10.9 \\
\hline GL & $5.3 *$ & $1.6^{\mathrm{ns}}$ & $2.6^{*}$ & 6.5 \\
\hline AA & $12.4 * *$ & $1.0^{\mathrm{ns}}$ & $1.1^{\mathrm{ns}}$ & 31.6 \\
\hline GSI & $9.6 *$ & $1.6^{\mathrm{ns}}$ & $2.5^{*}$ & 6.4 \\
\hline
\end{tabular}

ns, *,**: not significant, significant at 5 and $1 \%$ probability by $\mathrm{F}$ test, respectively; ${ }^{1} \mathrm{Y}=77.6+0.228 \mathrm{GF}-0.001 \mathrm{x}^{2} ; \mathrm{R}^{2}=0.99$.

For unfolding the irrigation management within each $\mathrm{N}$ rate, Penman-Monteith provided the highest $\mathrm{N}$ content in the seeds, regardless of the $\mathrm{N}$ topdressing rate. For unfolding $\mathrm{N}$ rates within each irrigation management, Hargreaves-Samani and Penman-Monteith provided quadratic adjustments to nitrogen content in the seeds (Table 4), being the maximum contents obtained with 94 and $72 \mathrm{~kg} \mathrm{ha}^{-1}$ $\mathrm{N}$, respectively, but there was no adjustment of this variable to $\mathrm{N}$ rates when used management by Class A pan. These results differ from those obtained by Farinelli et al. (2006), who assessing the physiological quality of common bean seeds in response to $\mathrm{N}$ rates did not observe increase in $\mathrm{N}$ content in the seeds, probably because in these studies there was no increase in $\mathrm{N}$ content in the plant.

Table 4. Unfolding of significant interaction between irrigation management and nitrogen topdressing rates for nitrogen and crude protein content in seeds, germination at laboratory and germination speed index in common bean seeds.

\begin{tabular}{|c|c|c|c|c|c|c|}
\hline \multirow{3}{*}{$\begin{array}{l}\text { Irrigation } \\
\text { management }\end{array}$} & \multicolumn{4}{|c|}{$\mathrm{N}$ rates $\left(\mathrm{kg} \mathrm{ha}^{-1}\right)$} & \multirow[t]{2}{*}{ Equation } & \multirow[t]{2}{*}{$\mathrm{R}^{2}$} \\
\hline & 0 & 50 & 100 & 150 & & \\
\hline & \multicolumn{5}{|c|}{ Nitrogen contente in seeds (\%) } & \\
\hline HS & $4.1 \mathrm{~b}$ & $4.0 \mathrm{c}$ & $5.2 \mathrm{a}$ & $4.2 \mathrm{~b}$ & $Y=3.9+0.0151 x-0.00008 x^{2}$ & 0.32 \\
\hline PM & $5.7 \mathrm{a}$ & $5.8 \mathrm{a}$ & $4.9 \mathrm{a}$ & $6.2 \mathrm{a}$ & $Y=5.9-0.0172 x+0.00012 x^{2}$ & 0.44 \\
\hline CAT & $4.3 \mathrm{~b}$ & $4.7 \mathrm{~b}$ & $4.3 \mathrm{~b}$ & $4.5 \mathrm{~b}$ & ----- & --- \\
\hline \multicolumn{7}{|c|}{ Crude protein content in seeds $(\%)$} \\
\hline HS & $25.6 \mathrm{~b}$ & $24.7 \mathrm{c}$ & $32.4 \mathrm{a}$ & $26.5 \mathrm{~b}$ & $Y=24.5+0.0945 x-0.0004 x^{2}$ & 0.32 \\
\hline PM & $35.9 \mathrm{a}$ & $36.2 \mathrm{a}$ & $30.7 \mathrm{a}$ & $38.5 \mathrm{a}$ & $Y=36.9-0.1077 x+0.0007 x^{2}$ & 0.44 \\
\hline CAP & $26.8 \mathrm{~b}$ & $29.2 \mathrm{~b}$ & $26.6 \mathrm{~b}$ & $28.0 \mathrm{~b}$ & ----- & --- \\
\hline \multicolumn{7}{|c|}{ Germination at laboratory (\%) } \\
\hline HS & 88 & 90 & $95 \mathrm{a}$ & $91 \mathrm{ab}$ & $Y=89.5-0.06 x$ & 0.66 \\
\hline PM & 92 & 97 & $85 \mathrm{ab}$ & $94 \mathrm{a}$ & ----- & --- \\
\hline CAP & 91 & 87 & $80 \mathrm{~b}$ & $83 \mathrm{~b}$ & ----- & --- \\
\hline \multicolumn{7}{|c|}{ Germination speed index } \\
\hline HS & 8.6 & $8.9 \mathrm{ab}$ & $9.4 \mathrm{a}$ & $8.9 \mathrm{a}$ & ----- & --- \\
\hline PM & 9.1 & $9.7 \mathrm{a}$ & $8.5 \mathrm{ab}$ & $9.3 \mathrm{a}$ & ----- & --- \\
\hline CAP & 8.7 & $8.5 \mathrm{~b}$ & $7.8 \mathrm{~b}$ & $7.9 \mathrm{~b}$ & $Y=8.7-0.06 x$ & 0.80 \\
\hline
\end{tabular}

HS: Hargreaves-Samani; PM: Penman-Monteith; CAT: Class A pan; Means followed by the same letter in the same column do not differ by Tukey's test at $5 \%$ probability. 
For unfolding the irrigation management within each $\mathrm{N}$ rate, Penman-Monteith resulted in higher crude protein content in seeds, regardless of the $\mathrm{N}$ topdressing rate. For unfolding $\mathrm{N}$ rates within each irrigation management, there were quadratic adjustments to the crude protein content in seeds with the use of Hargreaves-Samani and PenmanMonteith, being the maximum contents obtained with 118 and $77 \mathrm{~kg} \mathrm{ha}^{-1} \mathrm{~N}$, respectively; however, there was no adjustment of this variable to $\mathrm{N}$ rates when using the management by Class A pan. Similar results were obtained by Bordin et al. (2003), Gomes Junior et al. (2005), Toledo et al. (2009) and Gomes Junior et al. (2010), who found quadratic adjustment of crude protein in response to $\mathrm{N}$ topdressing rates, and the maximum contents achieved with rates between 70 and $120 \mathrm{~kg} \mathrm{ha}^{-1} \mathrm{~N}$.

Moreover, these results indicate that different $\mathrm{N}$ rates promote increase in the $\mathrm{N}$ content in the common bean seeds, resulting in a higher crude protein content. This occurs because the $\mathrm{N}$ absorbed by the plant combines itself with carbon skeletons to produce proteins that are broken, translocated and stored in grains in the form of proteins and amino acids (GOMES JUNIOR et al., 2005).

For unfolding the irrigation management within each $\mathrm{N}$ rate except control $\left(0 \mathrm{~kg} \mathrm{ha}^{-1} \mathrm{~N}\right)$, Penman-Monteith and Hargreaves-Samani promoted a higher percentage of germination at laboratory and emergency speed index. For unfolding $\mathrm{N}$ rates within each irrigation management, there were negative linear adjustments for germination at laboratory with the use of Hargreaves-Samani and for emergence speed index with use of Class A pan.

It can be seen in Table 5 that the irrigation management by Penman-Monteith provided appropriate rates for the accelerated aging test. According to Dias and Marcos Filho (1995), this test causes degenerative changes in the metabolism of common bean seeds, triggering the disintegration and loss of integrity on the membrane system of the cell.

Table 5. Average values of accelerated aging for different irrigation management in common bean.

\begin{tabular}{cc}
\hline Irrigation managements $(\mathrm{I})$ & Accelerated aging $(\%)$ \\
\hline Hargreaves-Samani & $48.4 \mathrm{~b}$ \\
Penman-Monteith & $71.8 \mathrm{a}$ \\
CAP & $48.0 \mathrm{~b}$ \\
\hline
\end{tabular}

Means followed by the same letter in the same column do not differ by Tukey's test at $5 \%$ probability.

Talking into account that the irrigation management by Penman-Monteith has also provided the highest values for $\mathrm{N}$ and for the crude protein content in the seeds, it is likely that with this management there was no reduction on the acid phosphatase and on the esterase enzymes activity. This was possibly due to the lower irrigation depth applied with this method (Table 2), which may have minimized the leaching of $\mathrm{N}$ and led to a greater uptake and nutrition by the plants, enhancing the inference performed by Lopes et al. (2011) that this method is the most accurate for estimating ETo, amongst the evaluated ones.

\section{CONCLUSIONS}

Irrigation management and nitrogen topdressing influences the nitrogen and crude protein content in seeds, germination at laboratory and germination speed index.

Levels between 70 and $120 \mathrm{~kg} \mathrm{ha}^{-1} \mathrm{~N}$ in conjunction with irrigation management by Hargreaves-Samani method provide better physiological quality of common bean seeds.

RESUMO: O objetivo deste trabalho foi verificar a influência de diferentes manejos de irrigação e doses de nitrogênio $(\mathrm{N})$ em cobertura sobre o teor de proteína e a qualidade fisiológica de sementes de feijão. O experimento foi conduzido na Universidade Estadual de Mato Grosso do Sul, Unidade Universitária de Aquidauana nos meses de junho a setembro de 2010. O delineamento experimental utilizado foi em blocos casualizados, em esquema de parcelas subdivididas, utilizando-se três blocos e duas replicações dentro de cada bloco. As parcelas corresponderam a três manejos de irrigação: Hargreaves-Samani, Penman-Montheith e Tanque Classe A. As subparcelas foram representadas por quatro doses de $\mathrm{N}$ aplicadas em cobertura (zero, 50, $100 \mathrm{e} 150 \mathrm{~kg} \mathrm{ha}^{-1}$ ). Foram avaliadas as seguintes variáveis: massa de cem grãos, teor de nitrogênio nas sementes, germinação a campo, germinação em laboratório, envelhecimento acelerado e 
índice de velocidade de germinação. Houve interação significativa entre os diferentes manejos de irrigação e as doses de $\mathrm{N}$ em cobertura para o teor de nitrogênio e proteína bruta nas sementes, germinação em laboratório e índice de velocidade de emergência. As doses entre 70 e $120 \mathrm{~kg} \mathrm{ha}^{-1}$ de N em cobertura em conjunto com o manejo de irrigação HargreavesSamani proporcionam melhor qualidade fisiológica de sementes de feijoeiro comum.

PALAVRAS-CHAVE: Phaseolus vulgaris. Germinação. Testes de vigor.

\section{REFERENCES}

ALLEN, R. G.; PEREIRA, L. S.; RAES, D.; SMITH, M. Pan evaporation method. In: Crop evapotranspiration: guidelines for computing crop requirements. Roma: FAO, p. 78-85, 1998. (Irrigation and Drainage, 56).

BORDIN, L.; FARINELLI, R.; PENARIOL, F. G.; FORNASIERI FILHO, D. Sucessão de cultivo de feijãoarroz com doses de adubação nitrogenada após adubação verde, em semeadura direta. Bragantia, Campinas, v. 62, n. 3, p. 417-428, 2003. https://doi.org/10.1590/S0006-87052003000300008

BRASIL. Regras para análise de sementes. Ministério da Agricultura, Pecuária e Abastecimento. Secretaria de Defesa Agropecuária. Brasília, DF: Mapa/ACS, 2009. 395p.

CARVALHO, N. M.; NAKAGAWA, J. Sementes: Ciência, Tecnologia e Produção. Jaboticabal: FUNEP, 2000. 588p.

CONAB: Companhia Nacional de Abastecimento. Acompanhamento da safra brasileira: Grãos 2013/2014. Décimo levantamento/Agosto 2014. Disponível em: <http://www.conab.gov.br>. Acesso em: 19 de agosto, 2014.

CRUSCIOL, C. A. C.; LIMA, E. V.; ANDREOTTI, M.; NAKAGAWA, J.; LEMOS, L. B.; MARUBAYASHI, O. N. Efeito do nitrogênio sobre a qualidade fisiológica, produtividade e características de sementes de feijão.

Revista Brasileira de Sementes, Londrina, v. 25, n. 1, p. 108-115, 2003. https://doi.org/10.1590/S010131222003000100017

DIAS, D. C. S. F., MARCOS FILHO, J. Testes de vigor baseados na permeabilidade das membranas celulares: II. Lixiviação de potássio. Informativo ABRATES, Londrina, v. 5, n. 1, p. 37-41, 1995.

FARINELLI, R.; LEMOS, L. B.; PENARIOL, F. G.; EGÉA, M. M.; GASPAROTO, M. G. Adubação nitrogenada de cobertura no feijoeiro, em plantio direto e convencional. Pesquisa Agropecuária Brasileira, Brasília, v. 41, n. 2, p. 307-312, 2006. https://doi.org/10.1590/S0100-204X2006000200016

FERREIRA, D. F. Sisvar: a computer statistical analysis system. Ciência e Agrotecnologia (UFLA), Lavras, v. 35, n. 6, p. 1039-1042, 2011. DOI: 10.1590/S1413-70542011000600001

GOMES JUNIOR, F. G.; SÁ, M. E. Proteína e qualidade de sementes de feijão (Phaseolus vulgaris L.) em função da adubação nitrogenada em plantio direto. Revista Brasileira de Sementes, Londrina, v. 32, n. 1, p. 34-44, 2010. https://doi.org/10.1590/S0101-31222010000100004

GOMES JUNIOR, F. G.; LIMA, E. R.; LEAL, A. J. F.; MATOS, F. A.; SÁ, M. E; HAGA, K. I. Teor de proteína em grãos de feijão em diferentes épocas e doses de cobertura nitrogenada. Acta Scientiarum, Maringá, v. 27, n. 3, p. 455-459, 2005.

LOPES, A. S.; OLIVEIRA, G. Q.; SOUTO FILHO, S. N.; GOES, R. J.; CAMACHO, M. A. Manejo de irrigação e nitrogênio no feijoeiro comum cultivado em sistema plantio direto. Revista Ciência Agronômica, Fortaleza, v. 42, n. 1, p. 51-56, 2011. https://doi.org/10.1590/S1806-66902011000100007 
MAGUIRE, L. D. Speed of germination-aid in selection and evolution for seedling emergence and vigor. Crop Science, Madison, v. 2, n. 2, p. 176-177, 1962. https://doi.org/10.2135/cropsci1962.0011183X000200020033x MARCOS FILHO, J. Teste de envelhecimento acelerado. In: KRZYZANOWSKI, F.C.; VIEIRA, R.D.; FRANÇA-NETO, J. B. (Ed.). Vigor de sementes: conceitos e testes. Londrina: ABRATES, 1999. p. 1-24.

OLIVEIRA, A. P.; PEREIRA, E. L.; BRUNO, R. L. A.; ALVES, E. U.; COSTA, R. F.; LEAL, R. F. R. Produção e qualidade fisiológica de sementes de feijão em função de fontes e doses de nitrogênio. Revista Brasileira de Sementes, Londrina, v. 25, n. 1, p. 49-55, 2003. https://doi.org/10.1590/S010131222003000100009

PACHECO, A.; OLIVEIRA, G. Q.; LOPES, A. S.; BARBOSA, A. S. Manejos de irrigação e nitrogênio na produção de feijoeiro sob plantio direto. Pesquisa Agropecuária Tropical, Goiânia, v. 42, n. 3, p. 323-330, 2012. https://doi.org/10.1590/S1983-40632012000300004

PEREIRA, A. R.; VILLA NOVA, N. A.; SEDIYAMA, G. C. Evapo(transpi)ração. Piracicaba: FEALQ, 1997.

SILVA, M. G.; ARF, O.; TEODORO, P. E. Nitrogen topdressing and application ways of fluazifop-p-butyl + fomesafen in weed control and agronomic performance of common bean. Anais da Academia Brasileira de Ciências, São Paulo, v. 87, p. 2301-2307, 2015. https://doi.org/10.1590/0001-3765201520140347

TEDESCO, M. J.; GIANELLO, C.; BISSANI, C. A. Análise de solo, plantas e outros materiais. Porto Alegre: Departamento de Solos, Faculdade de Agronomia, UFRGS, 1995. 174p. (Boletim Técnico, 5).

TOLEDO, M. Z.; FONSECA, N. R.; CÉSAR, M. L.; SORATTO, R. P.; CAVARIANI, C.; CURSICOL, C. A. C. Qualidade fisiológica e armazenamento de sementes de feijão em função da aplicação tardia de nitrogênio em cobertura. Pesquisa Agropecuária Tropical, Goiânia, v. 39, n. 2, p. 124-133, 2009.

VIEIRA, R. F.; CARVALHO, T. J. Importância do uso de sementes de feijão livres de patógenos. Informe Agropecuário, Belo Horizonte, v. 25, n. 223, p. 33-41, 2004. 